\title{
Pratylenchus penetrans, a potential risk in glasshouse-grown lettuce: population dynamics and damage threshold
}

\author{
Jolien Claerbout ${ }^{1,2}$, Jenny Neukermans ${ }^{3}$, Isabel VAndeVelde ${ }^{4}$, An Decombel ${ }^{5}$, \\ Nancy de Sutter ${ }^{1}$, Anne-Marie DeEren ${ }^{1}$, Sofie Venneman ${ }^{4}$, Peter Bleyaert ${ }^{5}$, \\ Monica HöfTE ${ }^{2}$ and Nicole VIAENE ${ }^{1,6, *}$ \\ ${ }^{1}$ Plant, ILVO (Flanders Research Institute for Agriculture, Fisheries and Food), \\ Burgemeester Van Gansberghelaan 96, 9820 Merelbeke, Belgium \\ ${ }^{2}$ Laboratory of Phytopathology, Department of Plants and Crops, Faculty of Bioscience Engineering, \\ Ghent University, Coupure Links 653, 9000 Ghent, Belgium \\ ${ }^{3}$ PCG (Provinciaal Proefcentrum voor de Groenteteelt Oost-Vlaanderen vzw), \\ Karreweg 6, 9770 Kruishoutem, Belgium \\ ${ }^{4}$ PSKW (Proefstation voor de Groenteteelt), Duffelsesteenweg 101, 2860 Sint-Katelijne-Waver, Belgium \\ ${ }^{5}$ Inagro vzw, Ieperseweg 87, 8800 Rumbeke-Beitem, Belgium \\ ${ }^{6}$ Nematology Research Unit, Department of Biology, Faculty of Sciences, Ghent University, \\ K.L. Ledeganckstraat 35, 9000 Ghent, Belgium
}

Received: 22 July 2019; revised: 8 October 2019 Accepted for publication: 8 October 2019; available online: 10 December 2019

\begin{abstract}
Summary - The root-lesion nematode, Pratylenchus penetrans, causes growth reduction in glasshouse-grown lettuce and is mainly controlled by chemical soil disinfestation. Integrated management strategies require more knowledge about the population dynamics and damage threshold densities. We monitored the population during 2.5 years in a commercial glasshouse by sampling soil in the same four $1 \mathrm{~m}^{2}$ spots at 0-30 cm and 30-60 cm depth. The grower grew lettuce in rotation with leek, applied 1,3-dichloropropene in summer and left the field fallow during winter. Growing leek reduced the nematode population slightly but chemical soil disinfestation lowered the numbers drastically, although $41 \%$ of the nematodes in the deeper layer survived. Black fallow resulted in a slight increase of the population, probably due to hatching. Two pot experiments with ten densities of $P$. penetrans were conducted to estimate the damage threshold for a summer and autumn cultivar ('Cosmopolia' and 'Brighton', respectively). The thresholds for lettuce weight were 669 and 3834 P. penetrans $(100 \mathrm{ml} \mathrm{soil})^{-1}$ in summer and autumn, respectively, but with considerable variability in estimated parameters. The thresholds for root damage were much lower: 204 and 48 P. penetrans $(100 \mathrm{ml} \mathrm{soil})^{-1}$. Nematode numbers did not increase on lettuce in the pot tests (maximum multiplication rate was 0.40 ) but increased slightly in the commercial setting. These results show that populations of $P$. penetrans build up slowly when butterhead lettuce is rotated with leek and fallow, but chemical soil disinfestation is required to avoid numbers resulting in root damage.
\end{abstract}

Keywords - Allium porrum (leek), field monitoring, Lactuca sativa, population density, root-lesion nematode, Seinhorst equation, tolerance limit, yield loss.

In Belgium, butterhead lettuce (Lactuca sativa) is mainly produced in soil in glasshouses as a monoculture with up to five harvests per year. In some cases, however, the production of lettuce is rotated with other crops, such as leek or celery. Occasionally, nematodes are associated with severe growth reduction of glasshouse-grown lettuce. In a Belgian survey, soil samples from 38 glasshouses were analysed in order to have more insight into the

* Corresponding author, e-mail: nicole.viaene@ilvo.vlaanderen.be

presence of plant-parasitic nematodes. The study revealed that the root-lesion nematode, Pratylenchus penetrans (Cobb, 1917) Filipjev \& Schuurmans-Stekhoven, 1941, was present in $18 \%$ of the glasshouses (unpubl. data, 2014). Pratylenchus penetrans is spread worldwide and has a broad host range of nearly 400 plant species. This migratory endoparasitic nematode causes severe damage to economically important crops such as maize, potato 
and cereals, as well as several vegetables (Castillo \& Vovlas, 2007). Damage on lettuce caused by $P$. penetrans was reported by Gracia et al. (1991), Kilpatrick et al. (1963), Moretti et al. (1981) and Olthof \& Potter (1973). Based on scientific and economic importance, root-lesion nematodes (Pratylenchus spp.) are ranked third after rootknot (Meloidogyne spp.) and cyst nematodes (Heterodera and Globodera spp.) (Jones et al., 2013).

Currently, growers mainly control nematodes in lettuce by chemical soil disinfestation, which is also applied to reduce several other soil-borne pathogens. Stricter phytosanitary regulations in Belgium, driven by increasing environmental concerns, demand a reduction in the use of chemicals for soil disinfestation. To set up integrated pest management strategies, knowledge about the population dynamics and the damage threshold of $P$. penetrans for lettuce is required. The damage threshold density of a nematode species for a certain crop can be estimated with the Seinhorst function, a mathematical model that describes the relationship between the initial nematode population density and the yield (Schomaker \& Been, 2003). Although Olthof \& Potter (1973) noticed damage by $P$. penetrans on field-grown lettuce at $6000 \mathrm{P}$. penetrans $(\mathrm{kg} \text { soil })^{-1}$, they did not define a threshold density. The knowledge of this threshold is important to provide good management advice for lettuce growers.

The objective of this study was to investigate the population dynamics of $P$. penetrans in glasshouse-grown butterhead lettuce under normal cropping practices. Therefore, one commercial glasshouse without other important plant-parasitic nematodes was selected from the Belgian survey conducted in 2014 . The nematode population was monitored at the commercial glasshouse during 2.5 years to gain insight into the factors influencing nematode densities. In addition, the damage threshold was estimated by growing lettuce in pots in the glasshouse and recording lettuce growth parameters over a wide range of $P$. penetrans population densities. The obtained knowledge will contribute to the set-up of integrated pest management tools and the reduction of chemical soil disinfestation.

\section{Materials and methods}

SPATIAL AND TEMPORAL DYNAMICS OF P. PENETRANS IN GLASSHOUSE LETTUCE IN ROTATION WITH LEEK

A glasshouse where $P$. penetrans was found in relatively high densities during a survey from 2014 (701 $P$. penetrans $(100 \mathrm{ml} \mathrm{soil})^{-1}$ in the $0-30 \mathrm{~cm}$ soil layer and 143 P. penetrans $(100 \mathrm{ml} \mathrm{soil})^{-1}$ in the $30-60 \mathrm{~cm}$ layer $)$ was selected for this study since no other important plantparasitic nematodes were observed. The lettuce grower followed a rotation pattern consisting of black fallow in winter, cultivation of leek (Allium porrum) from March until June and two crops of butterhead lettuce. Every year or every other year, chemical soil disinfestation was applied in summer between the lettuce crops. The soil texture in the glasshouse was a fine sand with $5.1 \%$ of carbon, a $\mathrm{pH}-\mathrm{KCl}$ of $5.8,38 \mathrm{~kg} \mathrm{NO}_{3}^{-} \mathrm{ha}^{-1}, 12 \mathrm{~kg} \mathrm{NH}_{4}{ }^{+} \mathrm{ha}^{-1}$, $2333 \mathrm{mg} \mathrm{P}_{2} \mathrm{O}_{5}$ and $480 \mathrm{mg} \mathrm{K}_{2} \mathrm{O}(1 \mathrm{soil})^{-1}$, according to a soil analysis of January 2016. The nutrient status of the soil was adjusted regularly by applying fertilisers as recommended for each crop and was based on yearly soil analyses.

The study was carried out on a plot where reduced lettuce growth caused by $P$. penetrans had been observed previously. Eight composite soil samples were taken after each harvest of lettuce and leek, chemical soil disinfestation and black fallow. Samples were taken at four spots (= replications) at every sampling event. A grid of one square metre $(0.75 \mathrm{~m} \times 1.4 \mathrm{~m})$ was positioned on the same spot at every sampling occasion and two samples of ten cores each were collected per grid; one from $0-30 \mathrm{~cm}$ depth using a $2.5-\mathrm{cm}$ diam. soil auger and one from $30-60 \mathrm{~cm}$ depth using a $3.5-\mathrm{cm}$ diam. soil auger. This resulted in sample sizes of 1.47 and 2.88 , respectively. In addition, eight randomly chosen leek plants with roots were harvested on each of the four grids 6 days before the last soil sampling (21 June 2018). At each sampling event, the grower was interviewed about the performance of the previous crop. Soil temperature was measured, except for the first sampling event. Samples were stored at $12^{\circ} \mathrm{C}$ and processed within 4 weeks.

The soil of each sample was thoroughly mixed and a subsample of $200 \mathrm{ml}$ was taken. The organic fraction was separated from the mineral fraction by washing the soil through a $850 \mu \mathrm{m}$ sieve (Chen et al., 2000). The organic fraction, collected on top of the sieve and containing mainly small root fragments, was mixed in tap water for 1 min with a Waring blender at high speed setting and added to the mineral fraction in a 11 beaker. At the final sampling event, leek roots were sampled separately from soil samples. Those leek roots with adhering soil were cut in $1 \mathrm{~cm}$ pieces and a $10 \mathrm{~g}$ subsample was mixed in tap water for $1 \mathrm{~min}$, and washed over a $850 \mu \mathrm{m}$ sieve into a 11 beaker. The nematodes were extracted using the automated zonal centrifuge (Hendrickx, 1995) programmed for processing half of the volume, corresponding to $100 \mathrm{ml}$ soil or $5 \mathrm{~g}$ roots. The obtained nematode suspension was collected in a glass 
beaker and subsequently transferred to a counting dish. Total numbers of $P$. penetrans and non-plant-parasitic nematodes were determined using a binocular microscope $(50 \times)$.

Nematode counts taken before planting and at harvest of the different crops represented the initial and final population density, respectively. These counts were used to determine the influence of the crops on the nematode population in the soil. If the data were normally distributed and variances were equal, the initial and final population density were compared using the Student's $t$-test. If those assumptions were not fulfilled, the Wilcoxon test was applied. Spearman's correlation was calculated to find out to what extent the numbers of $P$. penetrans were related to those of non-plant-parasitic nematodes. The strength and direction of the correlation between nematode numbers in the two soil layers was also examined by calculating Spearman's coefficient, as was the influence of temperature on nematode numbers. The statistical tests were performed at a confidence level of $P=0.05$.

\section{DAMAGE THRESHOLD FOR P. PENETRANS ON BUTTERHEAD LETTUCE}

Two pot experiments were carried out during two different seasons. The first experiment was conducted in autumn with butterhead lettuce 'Brighton' and a second experiment in summer conditions with 'Cosmopolia'.

\section{Multiplication of $\mathrm{P}$. penetrans}

Pratylenchus penetrans was multiplied on carrot discs (O'Bannon \& Taylor, 1968) and in pots on maize (Teklu et al., 2016) to ensure sufficient nematode numbers for the experiments. The population was originally collected from maize roots in Kinrooi (Belgium) and had been maintained on carrot discs since 2006. Culturing methods were slightly adapted from the original descriptions in the following ways. For the carrot disc method, carrots were washed with tap water, surface-sterilised with ethanol, peeled and cut in slices of 5-10 mm with a sterile knife in a laminar flow. Vermiform stages of $P$. penetrans were sterilised in 2000 ppm streptomycin sulphate overnight and washed three times with sterile water before inoculating them on the carrot discs (20-40 nematodes $\operatorname{disc}^{-1}$ ). The carrot discs were maintained in Petri dishes and incubated in the dark at $21^{\circ} \mathrm{C}$ for 3 months. After incubation, the discs were cut into pieces and placed on a Baermann funnel in the mist chamber to collect the nematodes.
Five maize seeds ('Koloris' and 'LG3220') were seeded in 61 pots filled with $5610 \mathrm{~g}$ silver sand on a layer of $390 \mathrm{~g}$ hydro grains. After 2 weeks, pots were infested at a rate of $8 P$. penetrans ( $g$ dry soil) ${ }^{-1}$ in four holes between the plants. Maize was grown for 3 months at $20^{\circ} \mathrm{C}$ day $/ 16^{\circ} \mathrm{C}$ night and $16 \mathrm{~h}$ light. Plants were watered and fertilised three times a week. At harvest, roots were carefully washed with tap water, cut in $1 \mathrm{~cm}$ pieces and placed on a Baermann funnel in a mist chamber. Nematodes were collected regularly from carrot discs and maize roots until sufficient inoculum of $P$. penetrans was obtained. The nematodes were stored at $4^{\circ} \mathrm{C}$ until being used in the experiments.

\section{Pot experiments}

Pots of $17 \mathrm{~cm}$ diam. and $16 \mathrm{~cm}$ height were filled with 1.61 heat-sterilised field soil (6\% clay, 20\% loam, $74 \%$ sand and $1.4 \%$ organic carbon) in both experiments. Lettuce was sown in peat blocks ( 1 seed per block of $5 \times$ $5 \times 5 \mathrm{~cm}^{3}$ ), provided by the practical research stations PCG and Inagro, and were transferred to the pots when plants reached the 4-6 leaf stage. The peat blocks with seedlings were in a $2 \mathrm{~cm}$ deep hole made in the sandy soil. This took place in autumn (5 October 2016) and spring (21 March 2018) for 'Brighton' and 'Cosmopolia', a popular winter and summer cultivar, respectively.

One day after lettuce planting, the soil in the pots was inoculated with nematode densities of $0,50,100$, 200, 400, 800, 1600, 3200, 6400 and 12800 nematodes $(100 \mathrm{ml} \mathrm{soil})^{-1}$. Separate suspensions were made for every nematode density, so that an identical volume $(80 \mathrm{ml})$ could be added to every pot. The inoculum was pipetted in four holes around each plant, each $5 \mathrm{~cm}$ deep. Immediately after applying the nematode suspension to the soil, the holes were carefully closed and plants were watered. Five replications for every density were used, except for the highest density where a shortage of inoculum only allowed four and three replicates with 'Brighton' and 'Cosmopolia', respectively.

Pots were organised in the glasshouse according to a randomised block design. Plants were watered and fertilised as needed and no pesticides were applied. The experiment with 'Brighton' was carried out during autumn (October-November 2016) at PCG, Kruishoutem, where pots were kept in a commercial glasshouse setting. Hence, the temperature fluctuated according to the season and was on average $15-20^{\circ} \mathrm{C}$ in the first part of the experiment and $10-15^{\circ} \mathrm{C}$ in the second part. Plants were harvested 8 weeks after planting. The experiment with the summer cultivar 'Cosmopolia' was performed in a glasshouse at 
ILVO, Merelbeke, under controlled conditions simulating summer: day and night temperatures were 20 and $16^{\circ} \mathrm{C}$, respectively, with $16 \mathrm{~h}$ light. These plants were harvested 6 weeks after planting.

Nematode damage was evaluated by measuring lettuce head and root weight, and scoring head colour, head development and root quality on a scale from 1-9. The head colour scale ranged from score 1 , very dark, indicating a stressed plant, to score 9, normal light green colour, for a healthy crop. The head development refers to the head shape, a very important parameter for the quality of the produce. When the head is open and hollow, score 1 is given, while for a qualitative closed and filled head score 9 is given. Root quality was also scored on a scale from 1 (very bad root quality, roots break easily, several root lesions) to 9 (very good root quality, no root lesions).

The final nematode population was determined for the organic and mineral fraction in each pot. The entire root system was carefully removed from the soil, rinsed with water and cut into $1 \mathrm{~cm}$ pieces. The soil from the pot was mixed and a 200-ml subsample was taken for nematode extraction. Root and soil samples were processed as described above. Adults and juveniles of $P$. penetrans were counted in the total nematode suspension, except where there were high numbers when a subsample of at least 200 nematodes was counted.

\section{STATISTICAL ANALYSIS AND MODELLING}

Lettuce quality as well as nematode reproduction was described as a function of the applied initial nematode densities $\left(P_{\mathrm{i}}\right)$, using the models developed by Seinhorst (1966, 1986, 1998).

\section{Lettuce quality}

Measurements, directly or indirectly related to the quality of the lettuce heads (head development, head colour, head weight, root quality and root weight) were averaged for every initial nematode density $\left(P_{\mathrm{i}}\right)$. The Seinhorst model with $Z=0.95$ was fitted to the averaged data (Seinhorst, 1986, 1998).

$$
\begin{array}{ll}
y=m+(1-m) \times 0.95^{P_{\mathrm{i}} / T-1} & \text { for } P_{\mathrm{i}}>T \\
y=1 \quad \text { for } P_{\mathrm{i}} \leqslant T &
\end{array}
$$

The parameters tolerance limit $(T)$ and relative minimum yield $(m)$ were estimated for all measurements.

\section{Population dynamics}

The $P_{\mathrm{f}}$ (final population) for every initial nematode density $\left(P_{\mathrm{i}}\right)$ was log transformed, averaged over all repli- cations and then back transformed. The maximum multiplication rate $(a)$ and the maximum population density $(M)$ for each experiment were estimated by modelling the relationship between $P_{\mathrm{i}}$ and $P_{\mathrm{f}}$. The equation for migratory nematodes with more than one generation per growing period was used (Seinhorst, 1966; Schomaker et al., 2013):

$$
P_{\mathrm{f}}=M \times P_{\mathrm{i}} /\left(P_{\mathrm{i}}+M / a\right)
$$

All datasets were analysed using $\mathrm{R}$ studio and run in $\mathrm{R}$-version 3.5.0. The goodness-of-fit of models was expressed as the coefficient of determination $\left(R^{2}\right)$. Statistical differences between the estimated parameters of the two experiments were analysed using the least significant difference (LSD) test at $P=0.05$.

\section{Results}

\section{THE OCCURRENCE OF P. PENETRANS IN GLASSHOUSE LETTUCE IN ROTATION WITH LEEK}

Different cultivars of butterhead lettuce were grown in rotation with leek in a commercial glasshouse during the 2.5 years of the study (Fig. 1). No aboveground symptoms indicating nematode damage were observed in any of the crops. The first soil samples were taken early in December 2015 after lettuce 'Gardia' (Fig. 1). They contained only few $P$. penetrans, most residing in the $30-60 \mathrm{~cm}$ soil layer $\left(10(100 \mathrm{ml} \text { soil })^{-1}\right)$ and about 500 non-plant-parasitic nematodes $(100 \mathrm{ml}$ soil $)^{-1}$ (Fig. 2A, B). Chemical soil disinfestation with 1,3-dichloropropene had been applied in June 2015 before the start of the observations and was applied again in August 2016. Immediately after removal of the plastic, 3 weeks after the nematicide treatment, $P$. penetrans was absent in the $0-30 \mathrm{~cm}$ layer and only $7 P$. penetrans $(100 \mathrm{ml}$ soil $)^{-1}$ were found in the $30-60 \mathrm{~cm}$ layer, a population decrease of $59 \%$. In addition, 93 and $90 \%$ of the non-plantparasitic nematodes were killed due to this application in the higher and lower soil layer, respectively. However, the number of non-plant-parasitic nematodes recovered better after one cropping of butterhead lettuce compared with the numbers of $P$. penetrans (Fig. 2B).

Every winter there was a 3-month period of black fallow during which the population of $P$. penetrans remained more or less the same or increased slightly (Fig. 2). In 2016 , the increase was mainly observed in the lower layer (from 10 to 85 P. penetrans $(100 \mathrm{ml} \mathrm{soil})^{-1}$ ), while in 2018 the numbers of $P$. penetrans increased in the upper soil layer (from 27 to 66 P. penetrans $\left.(100 \mathrm{ml} \text { soil })^{-1}\right)$. Many 


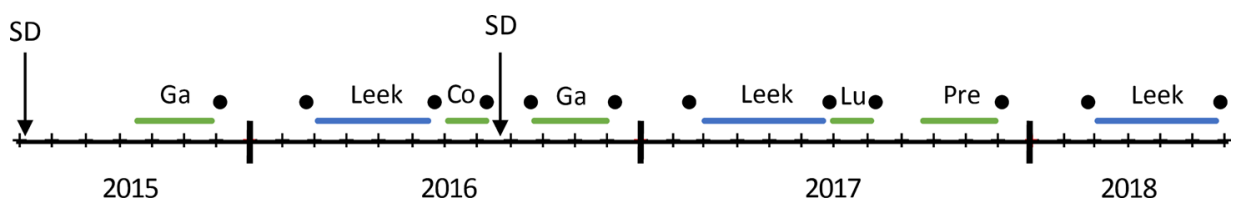

Fig. 1. Timeline of the crops grown in the commercial glasshouse starting in June 2015. The black dots represent the sampling time points. The green line represents the cultivation of butterhead lettuce with different cultivars ( $\mathrm{Ga}=$ ' $\mathrm{Gardia}$ ', $\mathrm{Co}=$ ' $\mathrm{Cosmopolia}$ ', $\mathrm{Lu}=$ 'Lucrecia' and Pre = 'Presteria'). The blue line represents the cultivation of leek 'Krypton'. SD = chemical soil disinfestation.

juveniles were observed in the samples after each period of black fallow.

Leek 'Krypton' was grown every year from March until the end of June. Its influence on the soil population density of $P$. penetrans was investigated by comparing the population densities in the soil before planting $\left(P_{\mathrm{i}}\right)$ and immediately after harvest $\left(P_{\mathrm{f}}\right)$ in both soil layers (Fig. 3A). In 2016, the population density decreased significantly in the lower soil layer. The densities of $P$. penetrans were too low to notice any changes in 2017 (Figs 2, 3A). In 2018, an increase was noticed in both soil layers but was not statistically significant. In 2018, roots were also investigated for the presence of $P$. penetrans. Elongated brown necrotic root lesions of $0.5 \mathrm{~cm}$ could be observed and $5 \mathrm{~g}$ of roots contained $1741 \pm 608$ vermiform stages of $P$. penetrans and $2188 \pm 700$ eggs $(n=4)$.

In general, growing butterhead lettuce resulted in no or just a slight increase in the numbers of $P$. penetrans in the soil (Fig. 3B). The only significant increase in nematode population density was observed in the $30-60 \mathrm{~cm}$ layer after growing butterhead lettuce 'Cosmopolia' in the summer of 2016. As 'Gardia' was grown after chemical soil disinfestation, not enough $P$. penetrans were left in the soil to notice differences in root-lesion nematode population densities. The numbers of $P$. penetrans increased, although not significantly, when growing 'Lucrecia' in the summer of 2017, and 'Presteria' in autumn 2017.

Overall, a weak linear correlation was found between the numbers of $P$. penetrans in the $0-30 \mathrm{~cm}$ layer and those in the $30-60 \mathrm{~cm}$ layer $(R=0.62, P<0.01$, Spearman correlation). This was also the case for the numbers of non-plant-parasitic nematodes $(R=0.64$, $P<0.01$, Spearman correlation). No correlation was found between the densities of $P$. penetrans and the densities of non-plant-parasitic nematodes $(R=0.28$, $P>0.05$, Spearman correlation), averaged over the $0-60 \mathrm{~cm}$ layer. Furthermore, there was no correlation between the population density of $P$. penetrans in the $0-60 \mathrm{~cm}$ layer and the ambient temperature $(R=0.01$, $P>0.05$, Spearman correlation) (data not shown).

\section{DAMAGE THRESHOLD FOR P. PENETRANS ON BUTTERHEAD LETTUCE}

Two pot experiments were carried out to determine the damage threshold for P. penetrans on lettuce. A first experiment was set up in autumn with 'Brighton' and a second in summer conditions with 'Cosmopolia'. The lettuce plants grew for 8 and 6 weeks in the first and second experiment, respectively.

\section{Weight and quality of lettuce heads}

The lettuce head weight ranged between 191 and $266 \mathrm{~g}$ and 95 and $147 \mathrm{~g}$ for 'Brighton' and 'Cosmopolia', respectively. Using the Seinhorst equation (1), a relative minimum weight $\left(m_{\mathrm{W}}\right)$ of 0.12 and 0.85 , and a maximum yield $\left(Y_{\max (\mathrm{W})}\right)$ of $249 \mathrm{~g}$ and $132 \mathrm{~g}$ were calculated for the two cultivars (Table 1$)$. The tolerance limit $\left(T_{\mathrm{W}}\right)$ was 3834 $P$. penetrans $(100 \mathrm{ml} \text { soil })^{-1}$ for 'Brighton' in autumn and 669 P. penetrans $(100 \mathrm{ml} \mathrm{soil})^{-1}$ for 'Cosmopolia' in summer conditions. No significant differences could be detected for the relative minimum weight and the tolerance limit between both cultivars.

Lettuce head development is of importance for the quality of the crop. A decline in quality could be observed with increasing numbers of $P$. penetrans in the soil (Fig. 4). The tolerance limit $\left(T_{\mathrm{D}}\right)$ for the head development was 185 and 1314 P. penetrans $(100 \mathrm{ml} \text { soil })^{-1}$ for 'Brighton' and 'Cosmopolia', respectively. The relative minimum scores for head development $\left(m_{\mathrm{D}}\right)$ were 0.79 and 0.39; the maximum scores for head development $\left(Y_{\max (\mathrm{D})}\right)$ were 6.23 and 7.64 (Table 2). No differences in colour of the lettuce heads could be noticed in pots with different densities of $P$. penetrans, for both experiments (data not shown).

\section{Root weight and quality}

Root weight and quality were measured as they affect head weight and development. The root weight ranged from 3.4 to $9.5 \mathrm{~g}$ and from 3.6 to $19.2 \mathrm{~g}$ for 'Brighton' grown in autumn and 'Cosmopolia' grown in summer conditions, respectively. An inverse relation was observed 


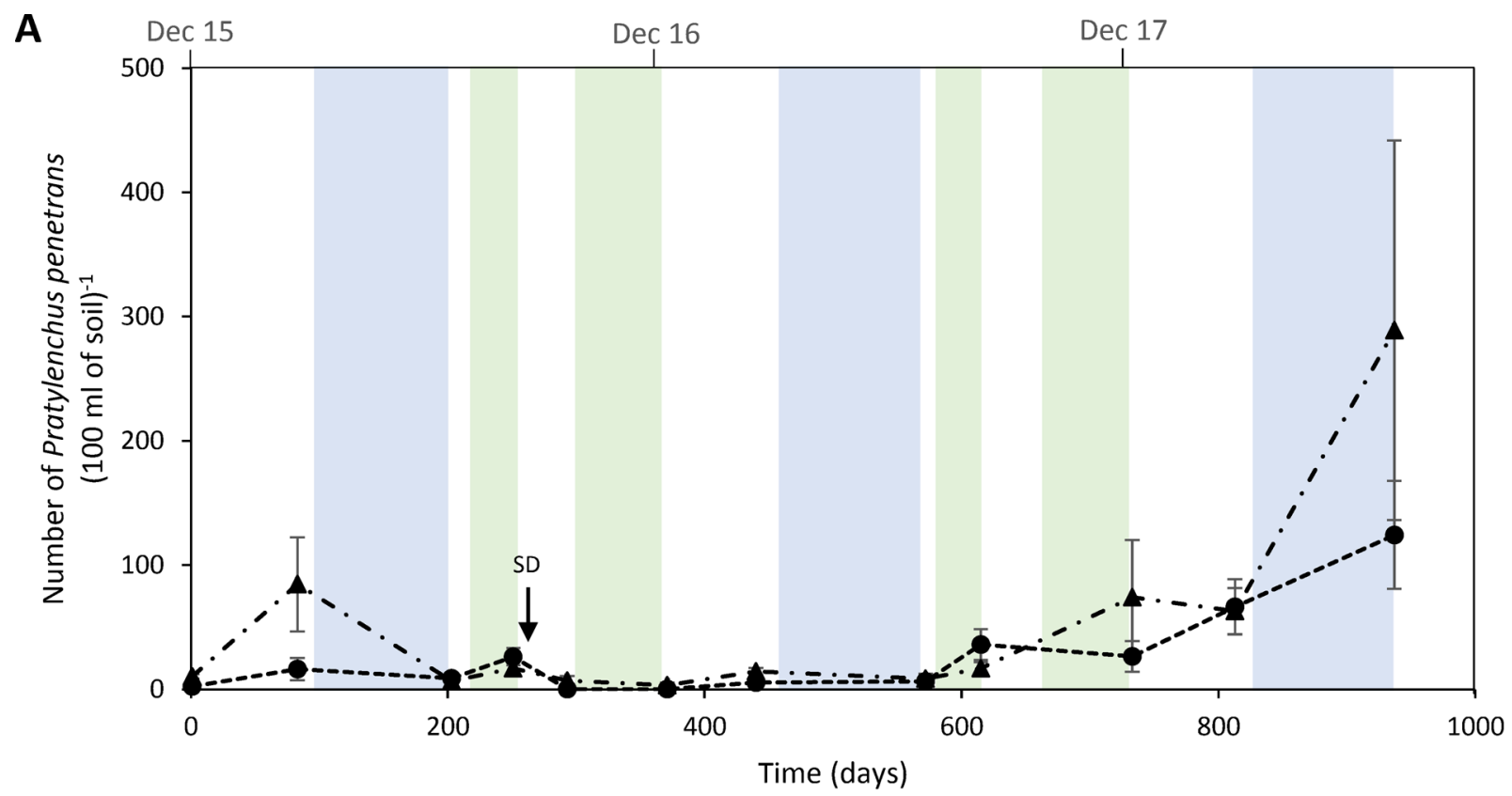

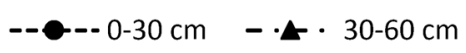

B

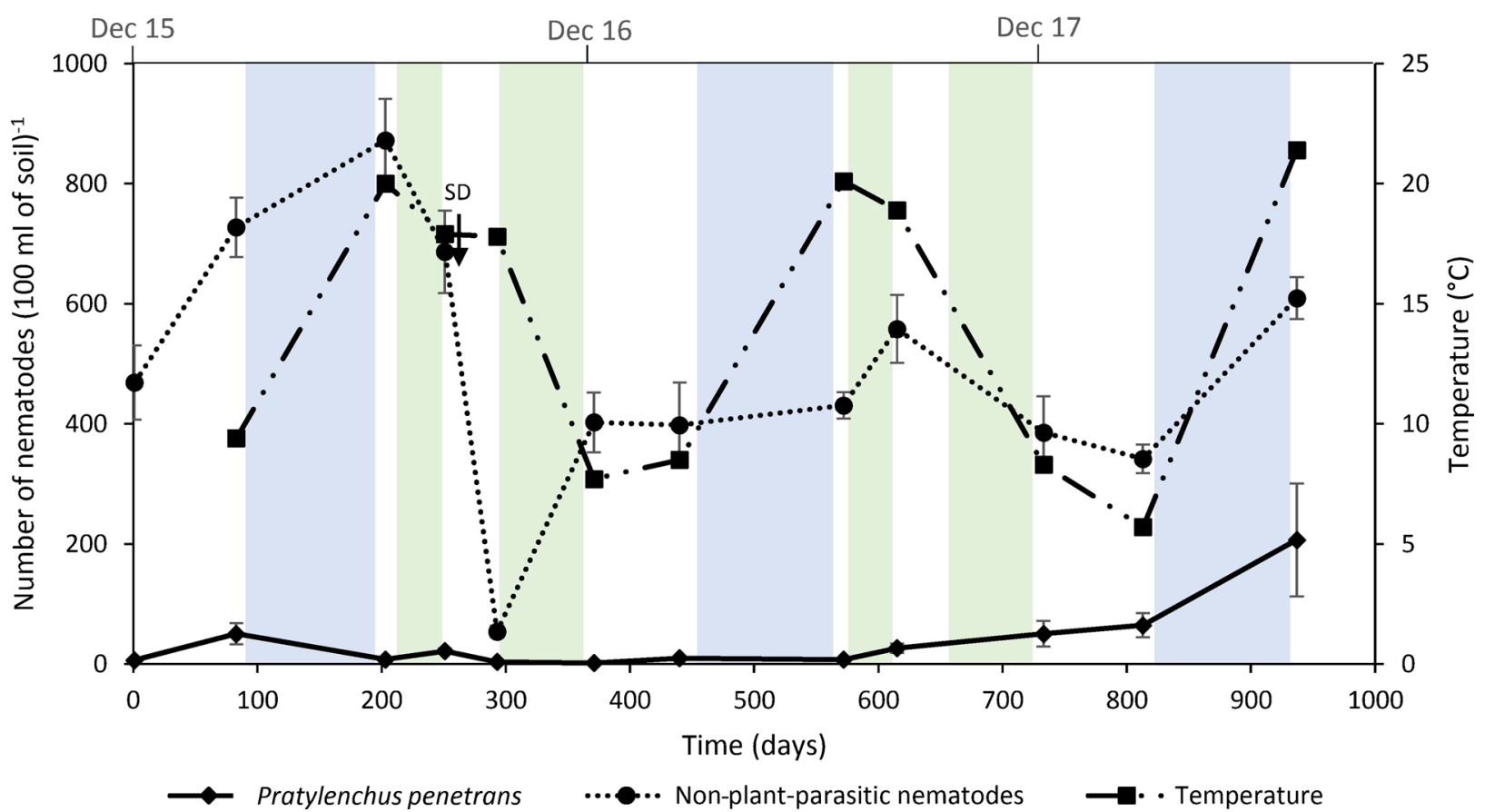

Fig. 2. A: Number of Pratylenchus penetrans $(100 \mathrm{ml} \text { soil })^{-1}$ in the $0-30$ and $30-60 \mathrm{~cm}$ soil layer. B: Number of $P$. penetrans and non-plant-parasitic nematodes $(100 \mathrm{ml} \text { soil })^{-1}$ averaged over the $0-60 \mathrm{~cm}$ soil layer and the ambient soil temperature over a period of 2.5 years. Day 1, the first sampling date, is 4 December 2015. Growing lettuce and leek is represented by the colours green and blue, respectively; white strips indicate black fallow. $\mathrm{SD}=$ chemical soil disinfestation. Error bars represent the standard error $(\mathrm{n}=4)$. 
A

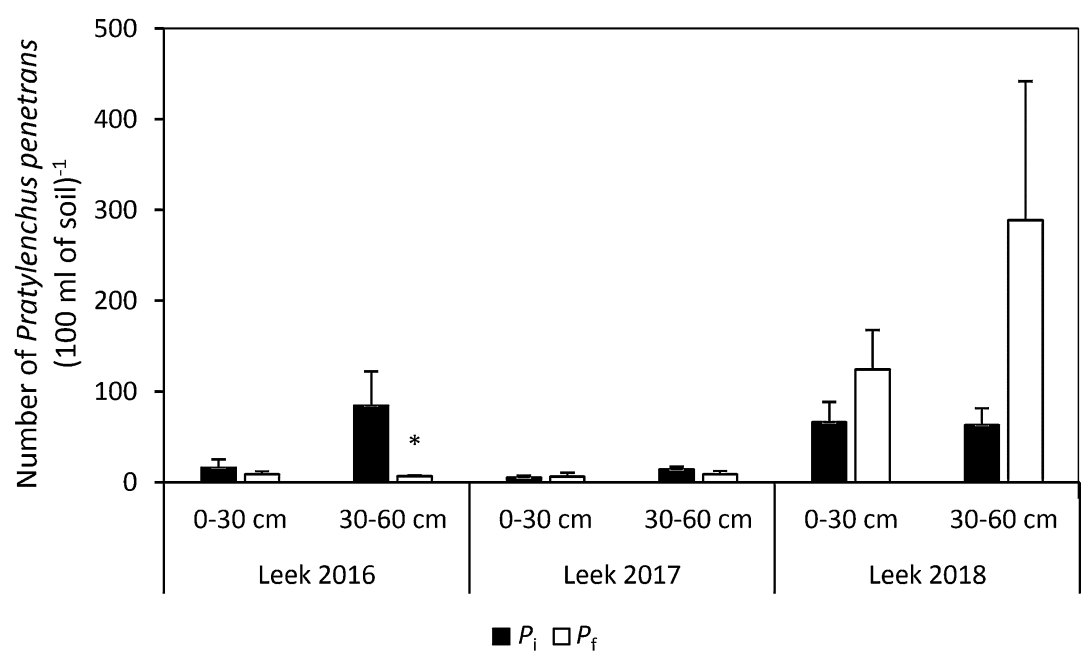

B

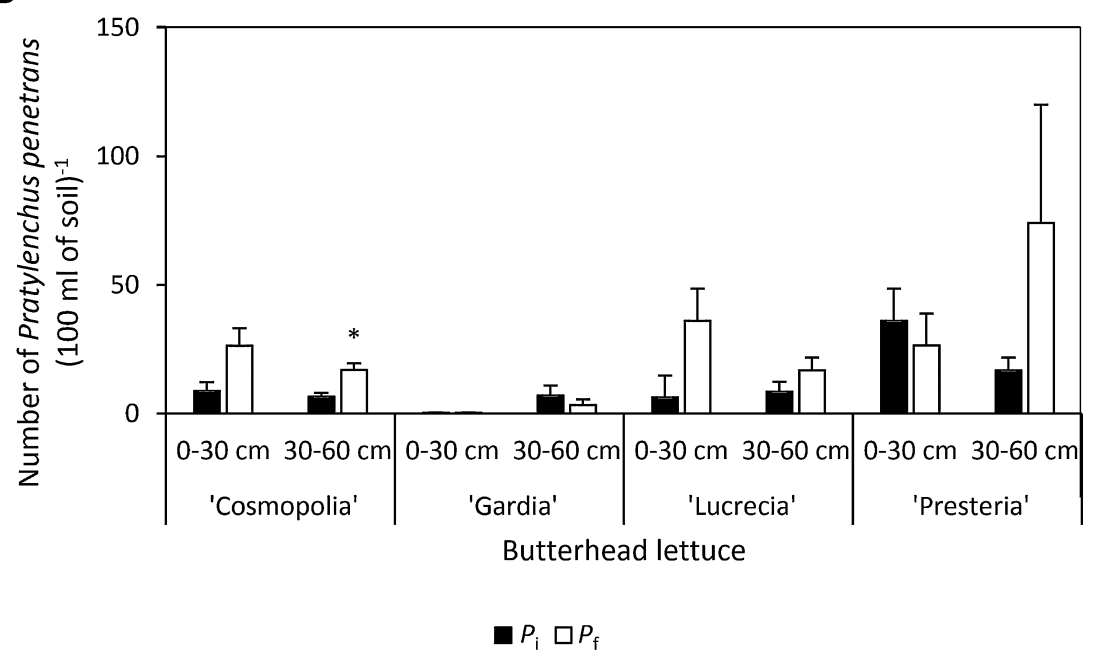

Fig. 3. The initial $\left(P_{\mathrm{i}}\right)$ and final $\left(P_{\mathrm{f}}\right)$ population density of Pratylenchus penetrans before and after growing A: Leek, B: different butterhead lettuce cultivars in the $0-30$ and $30-60 \mathrm{~cm}$ soil layer. Error bars represent the standard error $(\mathrm{n}=4)$. An asterisk $\left(^{*}\right)$ shows significant differences between $P_{\mathrm{i}}$ and $P_{\mathrm{f}}(P=0.05)$.

between root weight and nematode population density (Fig. 4). The relative minimum root weight $\left(m_{\mathrm{RW}}\right)$ was 0.76 and $0.51 \mathrm{~g}$ and the tolerance limit $\left(T_{\mathrm{RW}}\right)$ was 262 and 400 P. penetrans $(100 \mathrm{ml} \mathrm{soil})^{-1}$ for 'Brighton' and 'Cosmopolia', respectively. The maximum root weight $\left(Y_{\max (\mathrm{RW})}\right)$ was $6.25 \mathrm{~g}$ for 'Brighton' and $11.14 \mathrm{~g}$ for 'Cosmopolia' (Table 3). Additionally, root quality was affected by $P$. penetrans population density. The maximum root quality scores $\left(Y_{\max (\mathrm{Q})}\right)$ and the relative minimum root quality scores $\left(m_{\mathrm{Q}}\right)$ were similar for 'Brighton' and 'Cosmopolia': around 8 for $Y_{\max (\mathrm{Q})}$ and 0.6 for $m_{\mathrm{Q}}$ (Table 4).
However, there was a significant difference between the tolerance limits in both experiments; $T_{\mathrm{Q}}$ was 48 and $204 P$. penetrans $(100 \mathrm{ml} \mathrm{soil})^{-1}$ for 'Brighton' and 'Cosmopolia', respectively.

\section{Population dynamics}

The relation between $P_{\mathrm{i}}$ and $P_{\mathrm{f}}$ was very well described with the model for population dynamics (2) in both experiments $\left(R^{2}=0.96\right.$ and 0.99 ; Table 5). 'Brighton' and 'Cosmopolia' are both poor host for P. penetrans, because a decrease of the population was observed for every initial population density tested (Fig. 5). The maximum multi- 


\section{J. Claerbout et al.}

Table 1. Parameter values for the Seinhorst equations for the relation between initial population density $\left(P_{\mathrm{i}}\right)$ of Pratylenchus penetrans and lettuce head weight (g) according to the equation: $Y_{\mathrm{W}}=m_{\mathrm{W}}+\left(1-m_{\mathrm{W}}\right) 0.95^{P_{\mathrm{i}} / T_{\mathrm{W}}-1}$ for $P_{\mathrm{i}}>T_{\mathrm{W}}$ and $Y_{\mathrm{W}}=1$ for $P_{\mathrm{i}} \leqslant T_{\mathrm{W}}$.

\begin{tabular}{lrccccccccc}
\hline Cultivar & $T_{\mathrm{W}}$ & $m_{\mathrm{W}}$ & $Y_{\max (\mathrm{W})}$ & $\mathrm{SE}_{T(\mathrm{~W})}$ & $\mathrm{SE}_{m(\mathrm{~W})}$ & $\mathrm{SE}_{Y \max (\mathrm{W})}$ & $R^{2}$ & $\mathrm{df}$ & $\mathrm{LSD}_{T(\mathrm{~W})}$ & $\mathrm{LSD}_{m(\mathrm{~W})}$ \\
\hline 'Brighton' & 3834 & 0.12 & 248.69 & 2517 & 0.83 & 1.78 & 0.69 & 7 & - & - \\
'Cosmopolia' & 669 & 0.85 & 131.83 & 1178 & 0.19 & 1.73 & 0.46 & 7 & 5960 & 1.83 \\
\hline
\end{tabular}

$P_{\mathrm{i}}$ and the tolerance limit $(T)$ are expressed in P. penetrans $(100 \mathrm{ml} \text { soil })^{-1}$, while yield $(y)$ and relative minimum yield $(m)$ are proportions and the maximum yield $\left(Y_{\max }\right)$ is expressed in g. Parameter values of 'Brighton' grown in autumn were compared with those of 'Cosmopolia' grown in summer conditions using the LSD test. An asterisk $(*)$ shows significant differences $(P=0.05)$. SE $=$ standard error, $\mathrm{df}=$ degrees of freedom.

Table 2. Parameter values for the Seinhorst equations for the relation between initial population density $\left(P_{\mathrm{i}}\right)$ of Pratylenchus penetrans and lettuce head development according to the equation: $Y_{\mathrm{D}}=m_{\mathrm{D}}+\left(1-m_{\mathrm{D}}\right) 0.95^{P_{\mathrm{i}} / T_{\mathrm{D}}{ }^{-1}}$ for $P_{\mathrm{i}}>T_{\mathrm{D}}$ and $Y_{\mathrm{D}}=1$ for $P_{\mathrm{i}} \leqslant T_{\mathrm{D}}$.

\begin{tabular}{lcccccccccc}
\hline Cultivar & $T_{\mathrm{D}}$ & $m_{\mathrm{D}}$ & $Y_{\max (\mathrm{D})}$ & $\mathrm{SE}_{T(\mathrm{D})}$ & $\mathrm{SE}_{m(\mathrm{D})}$ & $\mathrm{SE}_{Y \max (\mathrm{D})}$ & $R^{2}$ & $\mathrm{df}$ & $\mathrm{LSD}_{T(\mathrm{D})}$ & $\mathrm{LSD}_{m(\mathrm{D})}$ \\
\hline 'Brighton' & 185 & 0.79 & 6.23 & 202 & 0.09 & 0.25 & 0.36 & 7 & - & - \\
'Cosmopolia' & 1314 & 0.39 & 7.64 & 1741 & 0.76 & 0.22 & 0.43 & 7 & 3759 & 1.65 \\
\hline
\end{tabular}

$P_{\mathrm{i}}$ and the tolerance limit $(T)$ are expressed in $P$. penetrans $(100 \mathrm{ml} \text { soil })^{-1}$, while yield $(y)$ and relative minimum yield $(m)$ are proportions and the maximum yield $\left(Y_{\max }\right)$ is expressed as a score between 1 and 9. Parameter values of 'Brighton' grown in autumn were compared with those of 'Cosmopolia' grown in summer conditions using the LSD test. An asterisk (*) shows significant differences $(P=0.05)$. SE $=$ standard error, $\mathrm{df}=$ degrees of freedom.

Table 3. Parameter values for the Seinhorst equations for the relation between initial population density $\left(P_{\mathrm{i}}\right)$ of Pratylenchus penetrans and lettuce root weight $(\mathrm{g})$ according to the equation: $Y_{\mathrm{RW}}=m_{\mathrm{RW}}+\left(1-m_{\mathrm{RW}}\right) 0.95^{P_{\mathrm{i}} / T_{\mathrm{RW}}-1}$ for $P_{\mathrm{i}}>T_{\mathrm{RW}}$ and $Y_{\mathrm{RW}}=1$ for $P_{\mathrm{i}} \leqslant T_{\mathrm{RW}}$.

\begin{tabular}{lcccccccccc}
\hline Cultivar & $T_{\mathrm{RW}}$ & $m_{\mathrm{RW}}$ & $Y_{\max (\mathrm{RW})}$ & $\mathrm{SE}_{T(\mathrm{RW})}$ & $\mathrm{SE}_{m(\mathrm{RW})}$ & $\mathrm{SE}_{Y \max (\mathrm{RW})}$ & $R^{2}$ & $\mathrm{df}$ & $\mathrm{LSD}_{T(\mathrm{RW})}$ & $\mathrm{LSD}$ \\
\hline$(\mathrm{RW})$ \\
\hline 'Brighton' & 262 & 0.76 & 6.25 & 312 & 0.14 & 0.26 & 0.30 & 7 & - & - \\
'Cosmopolia' & 400 & 0.51 & 11.14 & 173 & 0.15 & 0.43 & 0.62 & 7 & 765 & 0.44 \\
\hline
\end{tabular}

$P_{\mathrm{i}}$ and the tolerance limit $(T)$ are expressed in $P$. penetrans $(100 \mathrm{ml} \text { soil })^{-1}$, while yield $(y)$ and relative minimum yield $(m)$ are proportions and the maximum yield $\left(Y_{\max }\right)$ is expressed in g. Parameter values of 'Brighton' grown in autumn were compared with those of 'Cosmopolia' grown in summer conditions using the LSD test. An asterisk $(*)$ shows significant differences $(P=0.05)$. SE $=$ standard error, $\mathrm{df}=$ degrees of freedom.

Table 4. Parameter values for the Seinhorst equations for the relation between initial population density $\left(P_{\mathrm{i}}\right)$ of Pratylenchus penetrans and lettuce root quality according to the equation: $Y_{\mathrm{Q}}=m_{\mathrm{Q}}+\left(1-m_{\mathrm{Q}}\right) 0.95^{P_{\mathrm{i}} / T_{\mathrm{Q}}-1}$ for $P_{\mathrm{i}}>T_{\mathrm{Q}}$ and $Y_{\mathrm{Q}}=1$ for $P_{\mathrm{i}} \leqslant T_{\mathrm{Q}}$.

\begin{tabular}{lrccccccccc}
\hline Cultivar & $T_{\mathrm{Q}}$ & $m_{\mathrm{Q}}$ & $Y_{\max (\mathrm{Q})}$ & $\mathrm{SE}_{T(\mathrm{Q})}$ & $\mathrm{SE}_{m(\mathrm{Q})}$ & $\mathrm{SE}_{Y \max (\mathrm{Q})}$ & $R^{2}$ & $\mathrm{df}$ & $\mathrm{LSD}_{T(\mathrm{Q})}$ & $\mathrm{LSD}_{m(\mathrm{Q})}$ \\
\hline 'Brighton' & 48 & 0.66 & 8.41 & 21 & 0.03 & 0.26 & 0.90 & 7 & - & - \\
'Cosmopolia' & 204 & 0.60 & 8.01 & 50 & 0.04 & 0.12 & 0.95 & 7 & $115^{*}$ & 0.11 \\
\hline
\end{tabular}

$P_{\mathrm{i}}$ and the tolerance limit $(T)$ are expressed in $P$. penetrans $(100 \mathrm{ml} \text { soil })^{-1}$, while yield $(y)$ and relative minimum yield $(m)$ are proportions and the maximum yield $\left(Y_{\max }\right)$ is expressed as a score between 1 and 9. Parameter values of 'Brighton' grown in autumn were compared with those of 'Cosmopolia' grown in summer conditions using the LSD test. An asterisk (*) shows significant differences $(P=0.05)$. $\mathrm{SE}=$ standard error, $\mathrm{df}=$ degrees of freedom. 
A

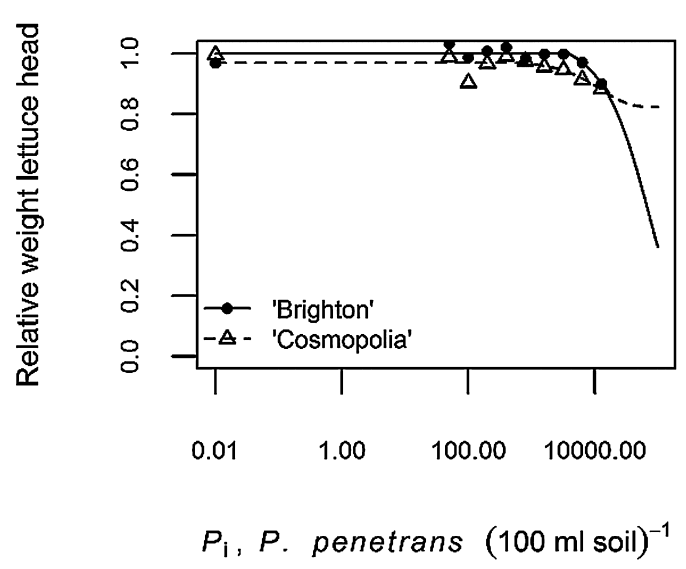

C

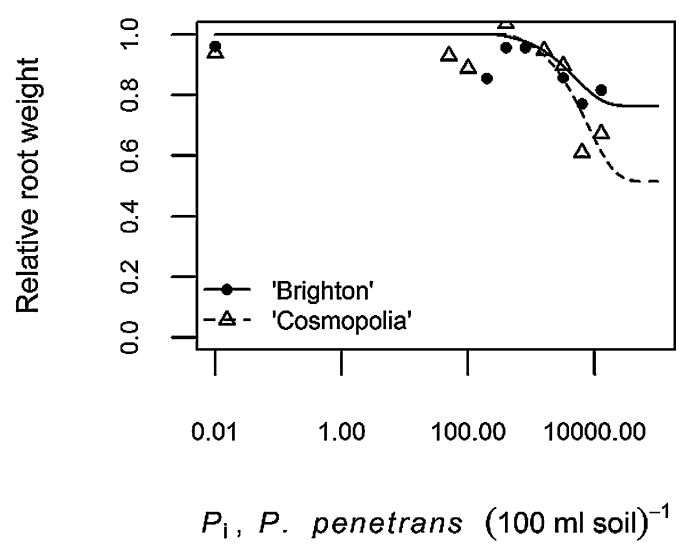

B

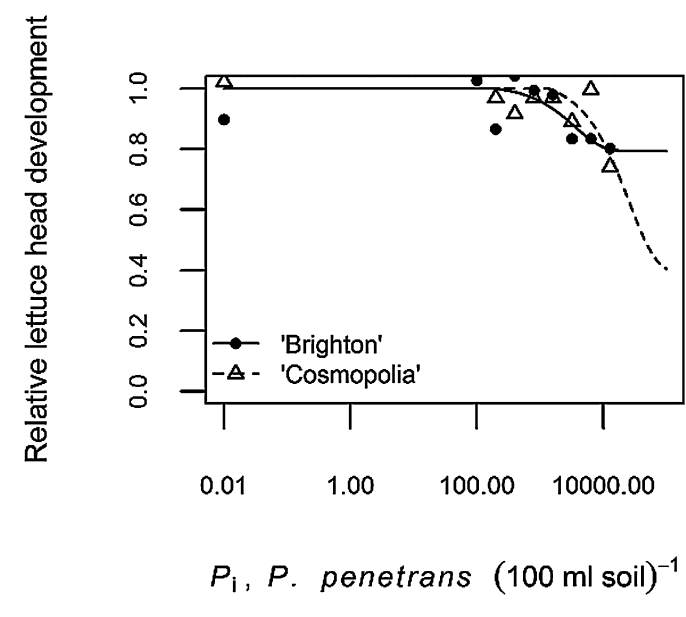

D

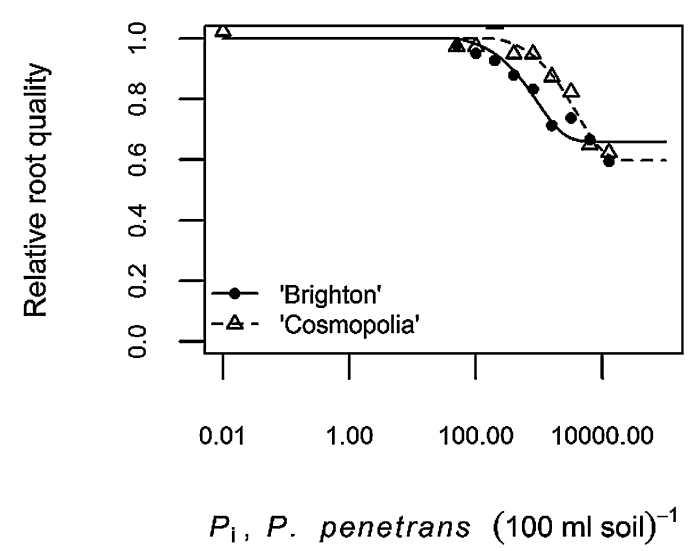

Fig. 4. The relation between the initial population density $\left(P_{\mathrm{i}}\right)$ of Pratylenchus penetrans and A: the relative weight of the lettuce head, $\mathrm{B}$ : the relative lettuce head development, $\mathrm{C}$ : the relative root weight and D: relative root quality for 'Brighton' grown in autumn and 'Cosmopolia' grown in summer conditions. A line was fitted according to the Seinhorst equation: $y=m+(1-m) 0.95^{P_{\mathrm{i}} / T-1}$ for $P_{\mathrm{i}}>T_{\mathrm{y}}$ and $y=1$ for $P_{\mathrm{i}} \leqslant T_{\mathrm{y}}$.

plication rate $(a)$ of the $P$. penetrans population was 0.31 for 'Brighton' and 0.40 for 'Cosmopolia' (Table 5). The maximum population density $(M)$ was 3609 and $13090 P$. penetrans $(100 \mathrm{ml} \mathrm{soil})^{-1}$ for 'Brighton' and 'Cosmopolia', respectively.

\section{Discussion}

To obtain more insight into the factors influencing the dynamics of a $P$. penetrans population in a commercial lettuce glasshouse, nematode population dynamics were monitored during a 2.5 year period. In addition, we set up pot tests to determine the damage threshold densi- ties of the root-lesion nematode for butterhead lettuce in summer and autumn croppings. Overall, numbers of $P$. penetrans were low in this study, which makes it hard to gain a deeper insight into factors influencing $P$. penetrans dynamics. Moreover, nematode numbers in the four replicated spots were highly variable. The annual use of the soil fumigant 1,3-dichloropropene most likely contributed to the low occurrence of $P$. penetrans (Zasada et al., 2010). Although nematode numbers declined considerably, nearly half $(41 \%)$ of the population in the $30-60 \mathrm{~cm}$ soil layer survived the application. This is not unexpected as it is known that a nematicide application cannot be $100 \%$ effective (Haydock et al., 2006). The surviving nematodes can migrate to the upper soil lay- 
ers when a new crop is planted and infect roots growing downwards, so they are a risk for future crops. Indeed, a slow return of the population in the $0-30 \mathrm{~cm}$ soil layer was noticed in the commercial glasshouse when sampling 1 year after the disinfestation. The mobility of $P$. penetrans depends on several factors, such as soil texture and water availability (Castillo \& Vovlas, 2007). The sandy soil in the glasshouse we monitored and the regular water supply were conducive to the upwards migration of remaining $P$. penetrans.

It is known that black fallow in general has a negative effect on the population of $P$. penetrans (Pudasaini et al., 2006; Viaene et al., 2006). However, it was reported that at low population densities the number of nematodes can remain the same (Grabau et al., 2017). Although low densities were observed in our study, the population

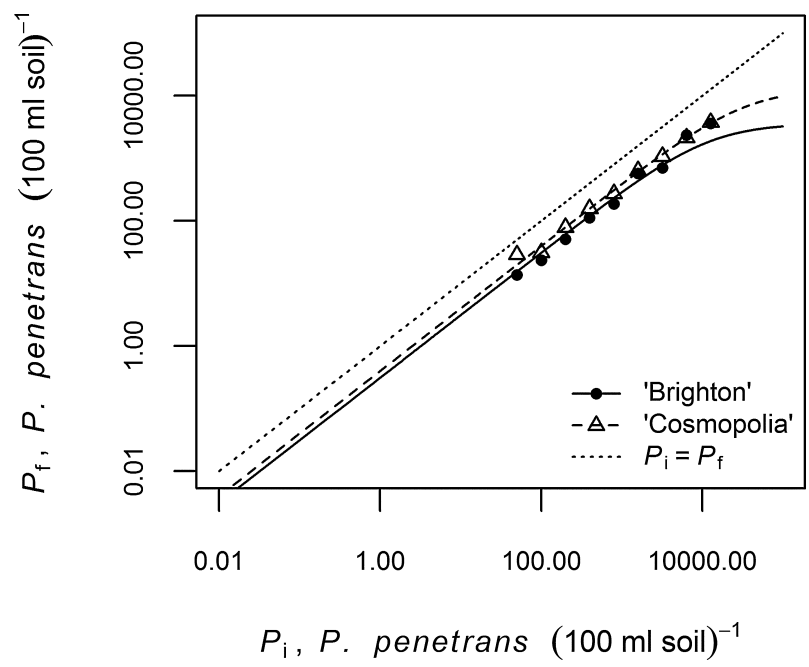

Fig. 5. The relation between the initial $\left(P_{\mathrm{i}}\right)$ and final $\left(P_{\mathrm{f}}\right)$ population density of Pratylenchus penetrans (roots and soil) for 'Brighton' grown in autumn and 'Cosmopolia' grown in summer conditions. A line was fitted according to the equation: $P_{\mathrm{f}}=M \times P_{\mathrm{i}} /\left(P_{\mathrm{i}}+M / a\right)$ for population dynamics. The diagonal dashed line represents the population equilibrium line $\left(P_{\mathrm{f}}=P_{\mathrm{i}}\right)$. surprisingly increased sometimes after 3 months of black fallow in winter. This contradictory result can probably be explained by hatching, since a lot of juveniles were observed at the end of the fallow period. Hatching of $P$. penetrans is influenced by the host species, temperature (Pudasaini et al., 2008) and soil moisture (Gaur \& Haque, 1987). During winter the soil temperature in non-heated glasshouses is around $4-6^{\circ} \mathrm{C}$ at $10-15 \mathrm{~cm}$ depth, which still allows the development of $P$. penetrans. Mokrini et $a l$. (2016) showed that the reproduction factor of different $P$. penetrans populations was $1.0-1.6$ on carrot discs incubated for 8 weeks and even 2.7-3.7 after 12 weeks at $10^{\circ} \mathrm{C}$. Dunn (1972) showed that P. penetrans can hatch even at $0-4^{\circ} \mathrm{C}$. The lettuce grower only watered the soil at the end of black fallow. We assume that the change of moisture content stimulated hatching of $P$. penetrans.

Eggs in the nematode suspensions after extraction of the soil samples were not counted as those from $P$. penetrans cannot be distinguished from eggs of other nematode species. The number of eggs before and after leek, fallow and lettuce could have explained some of the observations made in this study, especially if the observed increase in number was due to hatching from eggs already present, or due to reproduction of $P$. penetrans on the plants.

The population of $P$. penetrans decreased or remained the same after growing leeks. This is in contrast to Koot \& Kroonenbackbier (1999), who showed that leek is a good host for $P$. penetrans. At the last cropping cycle, besides taking soil samples, leek plants were also harvested and the roots were analysed for $P$. penetrans. Overall, $5 \mathrm{~g}$ roots contained $1741( \pm 608)$ P. penetrans, which corresponds with 16 P. penetrans $(100 \mathrm{ml} \mathrm{soil})^{-1}$ in the upper layer or $11 \%$ of the total soil population. Leek can be considered as a trap crop as the roots are removed from the soil at harvest. A growth reduction of leek was never observed, probably due to the low numbers in the glasshouse. Koot

Table 5. Parameter values of the population dynamics model for the relation between initial $\left(P_{\mathrm{i}}\right)$ and final population density $\left(P_{\mathrm{f}}\right)$ of Pratylenchus penetrans $(100 \mathrm{ml} \text { soil })^{-1}$ for 'Brighton' grown in autumn and 'Cosmopolia' grown in summer conditions, according to the model $P_{\mathrm{f}}=M \times P_{\mathrm{i}} /\left(P_{\mathrm{i}}+M / a\right)$.

\begin{tabular}{lrccccccc}
\hline Cultivar & $M$ & $a$ & $\mathrm{SE}_{M}$ & $\mathrm{SE}_{a}$ & $R^{2}$ & $\mathrm{df}$ & $\mathrm{LSD}_{M}$ & LSD $_{a}$ \\
\hline 'Brighton' & 3609 & 0.31 & 1247 & 0.05 & 0.96 & 7 & - \\
'Cosmopolia' & 13090 & 0.40 & 8180 & 0.03 & 0.99 & 7 & 1.43
\end{tabular}

Multiplication rate $(a)$ is dimensionless while maximum population $(M)$ is measured as $P$. penetrans $(100 \mathrm{ml} \text { soil })^{-1}$. Parameter values of 'Brighton' were compared with those of 'Cosmopolia' using the LSD-test $(P=0.05)$. SE $=$ standard error, df $=$ degrees of freedom.

* Significantly different at $P=0.05$. 
\& Kroonenbackbier (1999) observed a growth reduction of leek at 545 P. penetrans $(100 \mathrm{ml} \text { soil })^{-1}$.

Growing lettuce had a minor impact on the population of $P$. penetrans in the commercial glasshouse, even though lettuce is known as a good or maintenance host (Oostenbrink et al., 1957; Moretti et al., 1981). Moretti et al. (1981) showed that both temperature and cultivar play a role in the reproduction of $P$. penetrans. They observed a maximum population increase of 2.1 at $21-22^{\circ} \mathrm{C}$ with an initial population density of $250 P$. penetrans $(100 \mathrm{ml}$ soil $)^{-1}$, whilst at $14-15^{\circ} \mathrm{C}$ reproduction was reduced but not inhibited. In addition to reproduction, the length of the life cycle of $P$. penetrans also depends on temperature and can take between 3 and 8 weeks. According to Castillo \& Vovlas (2007) the life cycle of $P$. penetrans was 46, 38,28 and 26 days at $17,20,25$ and $27^{\circ} \mathrm{C}$, respectively. In the current study the temperature measured in the glasshouse at sampling before and after the first lettuce crop in summer was around $20^{\circ} \mathrm{C}$, while it was lower at the end of the second crop, indicating a life cycle duration of at least 38 days. Comparing soil temperatures with other Belgian glasshouses, the average soil temperature is estimated to be around $20^{\circ} \mathrm{C}$ and $13-14^{\circ} \mathrm{C}$ during the first and second lettuce crop, respectively. The first lettuce crop in the commercial glasshouse, 'Cosmopolia' grown in 2016, lasted 35 days and resulted in a small population increase. The other lettuce cultivars in the commercial glasshouse with growing periods of 48 days for the first crop and 91-95 days for the second crop did not affect the population density. In our pot experiments, summer conditions were simulated with a temperature of $16-20^{\circ} \mathrm{C}$ for 'Cosmopolia', but a decrease in $P$. penetrans numbers was observed with a maximum multiplication rate of 0.41 . The plants were grown for 42 days, barely enough to complete a life cycle at $16-20^{\circ} \mathrm{C}$ (Castillo \& Vovlas, 2007). Similarly, the population in the pot experiment during autumn with 'Brighton', lasting 56 days at $20^{\circ} \mathrm{C}$ and lower, had a maximum multiplication rate of 0.31 . The short periods that lettuce plants remain in the field could explain the small or lack of increase in P. penetrans. Lettuce grown outside in the field resulted in an increase of the population of $P$. penetrans in summer and even in autumn (Olthof \& Potter, 1973, 1974). This lettuce was planted in infested soil and grown for 57 days in summer (around $23^{\circ} \mathrm{C}$ ) and 75 days in autumn, respectively which allowed the completion of a life cycle. In addition, crisphead lettuce was used instead of butterhead lettuce, which can also influence reproduction.

Another reason for the lack of reproduction in the pot experiments could be the selected $P$. penetrans popula- tion. Pot tests were conducted with the Kinrooi population, originating from maize and cultured on carrot discs for more than 13 years. Tests with another population (PSKW), originating from lettuce and cultured on carrot discs and maize for only 2 years, did not result in different lettuce weights compared to Kinrooi (data unpubl.). However, the final populations of PSKW on lettuce 'Cosmopolia' were the same as the initial population, i.e., higher than those obtained with the Kinrooi population. The populations used in the studies of Olthof \& Potter $(1973,1974)$ and Moretti et al. (1981) were cultured on different hosts, including lettuce. Differences in reproduction and pathogenicity between $P$. penetrans populations have already been reported (Olthof, 1968; France \& Brodie, 1995; Castillo \& Vovlas, 2007) and could also explain the failure of $P$. penetrans to reproduce in our pot experiments. In addition, the extraction efficiency of the automated zonal centrifugation machine is not $100 \%$ and eggs are not counted, so the real population might be $10 \%$ higher than assumed.

Often the whole nematode community is used as a bioindicator to evaluate cultivation strategies or crop types (Neher \& Olson, 1999; Berkelmans et al., 2003; van Diepeningen et al., 2006; Quist et al., 2016). Large fluctuations in the number of non-plant-parasitic nematodes in the samples were observed during the monitoring but no link with the $P$. penetrans population was found. We hypothesised that soil fumigation would result in a significant reduction of beneficial nematodes and this could have been an explanation of the expected increase of $P$. penetrans (Timper et al., 2012). However, we observed a relatively fast rebound of the non-plant-parasitic nematodes after an initial decline immediately following fumigation but no considerable increase in $P$. penetrans. This could lead to the conclusion that an assumed competition between non-plant-parasitic nematodes and P. penetrans remained the same before and after chemical disinfestation, and that $P$. penetrans is suppressed by certain micro-organisms or other types of nematodes. We did not identify the composition of the nematode or the microbial community, so we were unable to check this hypothesis. However the explanation can also be found in the simple fact that $P$. penetrans needs time to build up its population, unlike the bacterial-feeding nematodes, and that regular application of nematicides in the commercial glasshouse we monitored does not allow this. In addition, lettuce and leek are slowing down the population build-up in the soil. Similar observations were made in a field study after application of 1,3-dichloropropene where it took years for the plant-parasitic nematodes Rotylenchus robustus, Tri- 
chodorus primitivus and Paratrichodorus pachydermus to reach their pre-fumigation densities (Boag \& Alphey, 1988). A more thorough investigation of the nematode community could be informative to work out relations between crop management practices and P. penetrans.

There are no reports of the damage threshold for $P$. penetrans in butterhead lettuce determined with the Seinhorst model. For crisphead lettuce, the damage threshold for Meloidogyne hapla was estimated to be 100-200 eggs $(100 \mathrm{ml} \mathrm{soil})^{-1}$ in microplots, and $700-800$ eggs $(100 \mathrm{ml} \mathrm{soil})^{-1}$ in pots (Viaene \& Abawi, 1996). In our study, the damage threshold for the crop weight was 669 and 3834 P. penetrans $(100 \mathrm{ml} \mathrm{soil})^{-1}$ in pots in summer and autumn conditions, respectively. Outside-grown transplanted crisphead lettuce showed losses in lettuce yield of 36 and $27 \%$ at initial population densities equivalent to $840 P$. penetrans $(100 \mathrm{ml} \text { soil })^{-1}$ in summer and autumn, respectively (Olthof \& Potter, 1973, 1974). In our study the damage threshold for the autumn-grown lettuce was much higher than the other reported thresholds but it was quite similar for the summer crop. Our pot experiments were conducted in heat-sterilised soil by which secondary infections that could have been present in the field in the autumn experiment were avoided. This might explain the fact that higher nematode populations were necessary to obtain yield losses in our pot test, next to the possible influence of cultivar, soil and climatic conditions. Furthermore, the standard errors for the calculated parameter values were very high and therefore the estimated damage thresholds should be interpreted with caution. This high variability is due to errors estimating $P_{\mathrm{i}}$ and yield; therefore, more repetitions should be included. Next to that, pot tests are indicative and field tests should be carried out to validate these results. For both pot tests, the damage thresholds for root weight and root quality were lower than those for crop weight, which means that damage on roots does not immediately result in lower crop weight.

No damage was observed on lettuce during the monitoring of the commercial glasshouse, probably due to the low densities of $P$. penetrans $(\leqslant 124$ P. penetrans $(100 \mathrm{ml}$ soil $)^{-1}$ ). However, in the summer of 2018 , the grower observed growth reduction in another glasshouse, where 220 P. penetrans $(100 \mathrm{ml} \text { soil })^{-1}$ and 323 P. penetrans $(5 \mathrm{~g}$ roots) ${ }^{-1}$ were counted in a soil sample taken after damage was observed. Furthermore, in the preliminary survey on lettuce, damage was found at a final population density of 701 P. penetrans $(100 \mathrm{ml} \text { soil })^{-1}$. In commercial lettuce production, heads should reach $450 \mathrm{~g}$ to be marketable. Plants in the pot experiments had maximum weights of
$266 \mathrm{~g}$ and $147 \mathrm{~g}$ in the autumn and summer crop, respectively. Therefore, it is strongly recommended to consider the damage thresholds calculated for root quality when making management decisions, because healthy roots will ensure a healthy lettuce head.

The damage threshold for $P$. penetrans can vary a lot between vegetables. The damage thresholds for $P$. penetrans for faba bean and carrot were $6.2(\mathrm{~g} \text { soil })^{-1}$ and 1.37-1.88 (g dry soil) ${ }^{-1}$, respectively (Seinhorst, 1998; Teklu et al., 2016). These numbers are equivalent to 868 and 192-263 P. penetrans $(100 \mathrm{ml} \mathrm{soil})^{-1}$. Other studies showed damage at $50 P$. penetrans $(100 \mathrm{ml} \mathrm{soil})^{-1}$ for bean; 0.45 P. penetrans (g soil) ${ }^{-1}$ (equivalent to $c a 63$ $\left.(100 \mathrm{ml} \mathrm{soil})^{-1}\right)$ for Brussels sprouts, cucumber, eggplant and tomato; $666 P$. penetrans $(\mathrm{kg} \text { soil) })^{-1}$ (equivalent to ca $\left.93(100 \mathrm{ml} \mathrm{soil})^{-1}\right)$ for onion; 6000 P. penetrans $(\mathrm{kg}$ soil $)^{-1}$ (equivalent to $\left.840(100 \mathrm{ml} \mathrm{soil})^{-1}\right)$ for cabbage, cauliflower, potato and 18000 P. penetrans $(\mathrm{kg} \text { soil })^{-1}$ (equivalent to $\left.2520(100 \mathrm{ml} \mathrm{soil})^{-1}\right)$ for beet and spinach (Olthof \& Potter, 1973, 1974; Miller, 1978; Elliott \& Bird, 1985). Our calculated damage thresholds are comparable with those for cabbage, cauliflower, potato, beet and spinach.

In conclusion, this study revealed that $P$. penetrans is a minor problem in glasshouse-grown lettuce but one that should not be overlooked. The population densities must be kept below 48-204 P. penetrans $(100 \mathrm{ml} \text { soil })^{-1}$ to secure a good root quality, necessary to obtain a marketable crop. However, other plant pathogens can also influence lettuce yield, so regular monitoring for pathogens as well as nematodes is highly recommended. Combining black fallow with a rotation of leek and lettuce seems to be a good practice to keep the nematode population low for at least 21 months. However, critical nematode densities might be achieved over time, requiring measures that reduce numbers effectively, such as chemical soil disinfestation. Lettuce growers should be aware that this management strategy does not kill all the nematodes and that the population of $P$. penetrans will recover slowly.

\section{Acknowledgements}

The authors wish to thank the lettuce grower for good collaboration. We thank Cindy Elisabeth for her technical assistance during the harvest of the pot experiments and soil extractions. We are grateful to Negin Ebrahimi for her valuable advice and discussions. This research was funded by grant No. 140984 from the Flanders Innovation \& Entrepreneurship (VLAIO). 


\section{References}

Berkelmans, R., Ferris, H., Tenuta, M. \& van Bruggen, A.H.C. (2003). Effects of long-term crop management on nematode trophic levels other than plant feeders disappear after 1 year of disruptive soil management. Applied Soil Ecology 23, 223235. DOI: 10.1016/S0929-1393(03)00047-7

Boag, B. \& Alphey, T.J.W. (1988). Influence of interspecific competition on the population dynamics of migratory plantparasitic nematodes with $\mathrm{r}$ and $\mathrm{K}$ survival strategies. Revue de Nematologie 11, 321-326.

Castillo, P. \& Vovlas, N. (2007). Pratylenchus (Nematoda: Pratylenchidae): Diagnosis, biology, pathogenicity and management. In: Hunt, D.J. \& Perry, R.N. (Series Eds). Nematology Monographs and Perspectives 6. Leiden, The Netherlands, Brill.

Chen, S., Hendrickx, G. \& Moens, M. (2000). The importance of organic matter when assaying Meloidogyne chitwoodi soil populations. Russian Journal of Nematology 8, 147-152.

Dunn, R.A. (1972). Importance of depth in soil, presence of host roots and role of eggs as compared to vermiform stages in overwintering of Pratylenchus penetrans at Ithaca, New York. Journal of Nematologys 4, 221-222.

Elliott, A.P. \& Bird, G.W. (1985). Pathogenicity of Pratylenchus penetrans to Navy bean (Phaseolus vulgaris L.). Journal of Nematology 17, 81-85.

France, R.A. \& Brodie, B.B. (1995). Differentiation of two New York isolates of Pratylenchus penetrans based on their reaction on potato. Journal of Nematology 27, 339-345.

Gaur, H.S. \& Haque, M.M. (1987). Effect of irrigation and stage of moisture stress on the growth of nematode populationi under pea. Indian Journal of Nematology 17, 189-192.

Grabau, Z.J., Maung, Z.T.Z., Noyes, D.C., Baas, D.G., Werling, B.P., Brainard, D.C. \& Melakeberhan, H. (2017). Effects of cover crops on Pratylenchus penetrans and the nematode community in carrot production. Journal of Nematology 49, 114-123. DOI: 10.21307/jofnem-2017-051

Gracia, J.A., Reeleder, R.D. \& Bélair, G. (1991). Interactions between Pythium tracheiphilum, Meloidogyne hapla and Pratylenchus penetrans on lettuce. Phytoprotection 72, 105114. DOI: $10.7202 / 706010 \mathrm{ar}$

Haydock, P.P.J., Woods, S.R., Grove, I.G. \& Hare, M.C. (2006). Chemical control of nematodes. In: Perry, R.N. \& Moens, M. (Eds). Plant nematology. Wallingford, UK, CAB International, pp. 392-410.

Hendrickx, G. (1995). An automated apparatus for extracting free-living nematode stages from soil. Nematologica 41, 308 . [Abstr.]

Jones, J.T., Haegeman, A., Danchin, E.G.J., Gaur, H.S., Helder, J., Jones, M.G.K., Kikuchi, T., Manzanilla-López, R., Palomares-Rius, J.E., Wesemael, W.M.L. et al. (2013). Top 10 plant-parasitic nematodes in molecular plant pathology. Molecular Plant Pathology 14, 946-961. DOI: 10.1111/mpp. 12057
Kilpatrick, R.A., Chen, T.-A., Rich, A.E. \& Rodrigues, L. (1963). Root symptoms and anatomical changes in clovers and lettuce resulting from injury by Pratylenchus penetrans and 2,4-dichlorophenoxyacetic acid. Phytopathology 53, 349.

Koot, P. \& Kroonenbackbier, B. (1999). Creatief omgaan met wortellesie-aaltje binnen de rotatie. PAV-Bulletin Vollegrondsgroenteteelt, 38-40.

Miller, P.M. (1978). Reproduction, penetration, and pathogenicity of Pratylenchus penetrans on tobacco, vegetables, and cover crops. Phytopathology 68, 1502-1504.

Mokrini, F., Waeyenberge, L., Viaene, N., Andaloussi, F.A. \& Moens, M. (2016). Diversity of root-lesion nematodes (Pratylenchus spp.) associated with wheat (Triticum aestivum and T. durum) in Morocco. Nematology 18, 1-21. DOI: 10. 1163/15685411-00002993

Moretti, F., Cotroneo, A. \& Mancini, G. (1981). The reproduction and pathology of Pratylenchus penetrans on some varieties of lettuce. Revue de Nématologie 4, 271-276.

Neher, D.A. \& Olson, R.K. (1999). Nematode communities in soils of four farm cropping management systems. Pedobiologia 43, 430-438.

O'Bannon, J.H. \& Taylor, A.L. (1968). Migratory endoparasitic nematodes reared on carrot discs. Phytopathology 58, 385386.

Olthof, T.H.A. (1968). Races of Pratylenchus penetrans, and their effect on black root rot resistance of tobacco. Nematologica 14, 482-488. DOI: 10.1163/187529268X00165

Olthof, T.H.A. \& Potter, J.W. (1973). The relationship between population densities of Pratylenchus penetrans and crop losses in summer-maturing vegetables in Ontario. Phytopathology 63, 577-582. DOI: 10.1094/Phyto-63-577

Olthof, T.H.A. \& Potter, J.W. (1974). Yield losses in fallmaturing vegetables relative to population densities of Pratylenchus penetrans and Meloidogyne hapla. Phytopathology 64, 1072-1075. DOI: 10.1094/Phyto-64-1072

Oostenbrink, M., S'Jacob, J.J. \& Kuiper, K. (1957). Over de waardplanten van Pratylenchus penetrans. Tijdschrift over Plantenziekten 63, 345-360.

Pudasaini, M.P., Viaene, N. \& Moens, M. (2006). Effect of marigold (Tagetes patula) on population dynamics of Pratylenchus penetrans in a field. Nematology 8, 477-484. DOI: 10.1163/156854106778613930

Pudasaini, M.P., Viaene, N. \& Moens, M. (2008). Hatching of the root-lesion nematode, Pratylenchus penetrans, under the influence of temperature and host. Nematology 10, 47-54. DOI: $10.1163 / 156854108783360078$

Quist, C.W., Schrama, M., de Haan, J.J., Smant, G., Bakker, J., van der Putten, W.H. \& Helder, J. (2016). Organic farming practices result in compositional shifts in nematode communities that exceed crop-related changes. Applied Soil Ecology 98, 273-279. DOI: 10.1016/j.apsoil.2015.10.022

Schomaker, C.H. \& Been, T.H. (2013). Plant growth and population dynamics. In: Perry, R.N. \& Moens, M. (Eds). Plant nematology, 2nd edition. Wallingford, UK, CAB International, pp. 275-301. DOI: 10.1079/9781780641515.0301 
Seinhorst, J.W. (1966). The relationships between population increase and population density in plant parasitic nematodes. Nematologica 12, 157-169. DOI: 10.1163/ 187529267 X00670

Seinhorst, J.W. (1986). Effect of nematode attack on the growth and yield of crop plants. In: Lamberti, F. \& Taylor, C.E. (Eds). Cyst nematodes. New York, NY, USA, Plenum Press, pp. 211228.

Seinhorst, J.W. (1998). The common relation between population density and plant weight in pot and microplot experiments with various nematode plant combinations. Fundamental and Applied Nematology 21, 459-468.

Teklu, M.G., Meressa, B.H., Radtke, E., Been, T.H. \& Hallmann, J. (2016). Damage thresholds and population dynamics of Pratylenchus penetrans on carrot (Daucus carota L. cv. Nerac) at three different seed densities. European Journal of Plant Pathology 146, 117-127. DOI: 10.1007/s10658-0160898-6

Timper, P., Davis, R., Jagdale, G. \& Herbert, J. (2012). Resiliency of a nematode community and suppressive service to tillage and nematicide application. Applied Soil Ecology 59, 48-59. DOI: 10.1016/j.apsoil.2012.04.001

van Diepeningen, A.D., de Vos, O.J., Korthals, G.W. \& van Bruggen, A.H.C. (2006). Effects of organic versus conventional management on chemical and biological parameters in agricultural soils. Applied Soil Ecology 31, 120-135. DOI: 10.1016/j.apsoil.2005.03.003

Viaene, N., Coyne, D.L. \& Kerry, B.R. (2006). Biological and cultural management. In: Perry, R.N. \& Moens, M. (Eds). Plant nematology. Wallingford, UK, CAB International, pp. 346-369. https://www.cabi.org/cabebooks/ebook/ 2006310971.

Viaene, N.M. \& Abawi, G.S. (1996). Damage threshold of Meloidogyne hapla to lettuce in organic soil. Journal of Nematology 28, 53-545.

Zasada, I.A., Halbrendt, J.M., Kokalis-Burelle, N., LaMondia, J., Mckenry, M.V. \& Noling, J.W. (2010). Managing nematodes without methyl bromide. Annual Review of Phytopathology 48, 311-328. DOI: 10.1146/annurev-phyto073009-114425 